О.С. Зав'ялов, завідувач сектору сертифікації стандартних зразків наркотичних засобів, психотропних речовин, їх аналогів та прекурсорів відділу досліджень наркотичних засобів, психотропних речовин, їх аналогів та прекурсорів табораторії досліджень матеріалів, речовин і виробів, Державний науково-дослідний експертнокриміналістичний иентр МВС Украӥни, м. Київ ORCID: https://orcid.org/0000-0002-4697-0841

Н. Є. Зав'ялова, головний судовий експерт відділу фізико-хімічних досліджень лабораторії досліджень матеріалів, речовин і виробів, Державний науково-дослідний експертнокриміналістичний центр МВС України, м. Київ ORCID: https://orcid.org/0000-0002-6483-8190

\title{
ДОСЛІДЖЕННЯ РІДИН, ЗАСТОСОВУВАНИХ В ЕЛЕКТРОННИХ ПРИСТРОЯХ ДЛЯ КУРІННЯ
}

\begin{abstract}
Mema статті полягає в розробленні деяких теоретичних положень і науково-обгрунтованих практичних рекомендацій щодо дослідження рідин, застосовуваних в електронних пристроях для куріння, зокрема послідовності пробопідготовки рідин на основі гліцериново-пропіленгліколевих сумішей, використовуваних в електронних сигаретах, для подальшого їх якісного та кількісного дослідження із застосуванням методів хромато-мас-спектрометрії і газорідинної хроматографії. Методологія. Методологічну основу дослідження становлять загальнонаукові та часткові методи наукового пізнання, комплексне застосування яких дозволило чітко окреслити мету й завдання дослідження в контексті взаємопоєднання наукових здобутків і потреб судово-експертної практики. При цьому за допомогою емпіричних методів (складника загальнонаукових або загальнологічних методів під кутом зору логіки пізнавального процесу), таких як опис, аналіз, вимірювання, порівняння, спостереження, експеримент проаналізовано рідини для вейпорайзерів, виготовлені з використанням наркотичних засобів і психотропних речовин, отриманих із рослин конопель, коли відсутність характерного їдкого диму дозволяє маскувати їх вживання таким способом; проаналізовано та експериментально перевірено можливість якісного і кількісного визначення тетрагідроканабінолу методом газорідинної хроматографії з мас-селективним та полум'яно-іонізаційним детектуванням, окреслено особливості таких досліджень. Часткові методи застосовано для дослідження конкретних явищ хімічної та біологічної природи. Математичними методами здійснено проміжні та остаточні розрахунки експерименту. Наукова новизна. Розроблено і відпрацьовано методологію пробопідготовки дослідження рідин на основі гліцериново-пропіленгліколевих сумішей, використовуваних в електронних сигаретах, для подальшого їх якісного та кількісного дослідження із застосуванням методів хромато-мас-спектрометрії та газорідинної хроматографії. Bисновки. Окреслено основні проблеми дослідження гліцериново-пропіленгліколевих рідин та їх сумішей, зокрема на етапі пробопідготовки, коли за браком чіткої методичної регламентації цього процесу експерти мусять вдаватися до експериментального підбору оптимального розчинника для екстракції та самостійно встановлювати послідовність їі проведення з метою їх подальшого гравіметричного (визначення сухого залишку екстракту канабісу) і газохроматографічного (кількісного визначення тетрагідроканабінолу) дослідження; запропоновано методологію пробопідготовки дослідження рідин на основі гліцериново-пропіленгліколевих сумішей, використовуваних в електронних сигаретах, для подальшого їх якісного та кількісного дослідження із застосуванням методів хромато-мас-спектрометрії та газорідинної хроматографії; експериментально доведено неможливість кількісного (а в окремих випадках і якісного) визначення тетрагідроканабінолу методом газорідинної хроматографії з полум'яно-іонізаційним детектуванням через наявність у складі гліцериново-пропіленгліколевих рідин речовин, які мають близький до тетрагідроканабінолу час утримання та «виходять» із хроматографічної колонки разом із ним одним аналітичним сигналом («піком»). Підтверджено можливість вирішення цього завдання за допомогою хромато-мас-спектрометричного комплексу із застосуванням методу вибіркового сканування іонів (Selective Ion Monitoring) у разі, коли неможливо підібрати умови для хроматографічного розділення тетрагідроканабінолу в суміші з іншими супутніми компонентами; проаналізовано отримані експериментальним шляхом дані порівняльного дослідження екстракції тетрагідроканабінолу із водних розчинів рідин для паріння трьома різними органічними розчинниками, у результаті з'ясовано, що діетиловий ефір проявляє дещо кращі екстракційні властивості щодо досліджуваного об'єкта, проаналізовано способи приготування наркотичних засобів і психотропних речовин, отриманих із рослин конопель, на основі рідин для вейпорайзерів. Наголошено на тому, що ці способи приготування відносно
\end{abstract}


нескладні, а відсутність характерного їдкого диму дозволяє маскувати їх вживання. Тому убачається на часі, оскільки формування демократичного суспільства і розбудова інституцій правової держави потребують унормування усіх сфер життєдіяльності суспільства, на законодавчому рівні розтлумачити і чітко дефініювати поняття «електронні сигарети», врегулювати їх обіг, зважаючи на ті ризики, що сьогодні постають перед державою.

Ключові слова: екстракт канабісу; тетрагідроканабінол; канабідіол; хромато-мас-спектрометрія; газорідинна хроматографія; електронна сигарета (вейпорайзер).

\section{Вступ}

3 появою сучасних електронних пристроїв для куріння (паріння) - електронних сигарет (е-сигарет, вейпів, вейпорайзерів), в яких використовуються легальні ароматизовані рідини на основі гліцерину та пропіленгліколю, поглиблюється, зокрема, проблема зловживання наркотичними засобами і психотропними речовинами, які отримують із рослин роду коноплі, оскільки незрідка їх додають до таких сумішей.

Відповідно до Методичних рекомендацій щодо класифікації товарів промислової продукції електронна сигарета являє собою мікроелектронний пристрій, що працює на елементі живлення і в якому потік повітря під час вдихання активізує парогенератор (випарник); при цьому рідина, що в ньому, нагріваючись, перетворюється на пару, яка нагадує тютюновий дим, імітуючи традиційний процес куріння сигарет (Pro vprovadzhennia metodychnykh rekomendatsii, 2014).

Основу рідини, використовуваної для отримання пари в електронних сигаретах, зазвичай становить суміш гліцерину і пропіленгліколю у співвідношенні 70:30. До суміші або замість пропіленгліколю, щоб гліцерин набув меншої в'язкості, можуть додавати дистильовану воду. Для прикладу, температура кипіння водно-гліцеринової суміші із вмістом води $10 \%$ знижується з $290^{\circ} \mathrm{C}$ (температура кипіння гліцерину) до $138^{\circ} \mathrm{C}$. Коли рідину для паріння готують без пропіленгліколю $\left(t_{\text {кип. }}=187,4{ }^{\circ} \mathrm{C}\right.$ за 760 мм рт. ст. $)$, до гліцерину додають дистильовану воду обсягом до $20 \%$. Така рідина утворює більше пари, але гірше передає аромати і смак (Obzor komponentov, 2015).

За легального використання до основи рідини для паріння найчастіше додають суміш ароматизаторів і нікотин. Нікотин має доволі високу температуру кипіння $\left(t=247^{\circ} \mathrm{C}\right.$ за 760 мм рт. ст.), що в електронній сигареті досягається не 3 перших секунд куріння. Але коли у складі суміші є пропіленгліколь або вода, температура кипіння яких у 2,5 раза нижча, вона закипає набагато швидше. Відповідно нікотин випаровується з водяною парою за набагато меншої температури (Nicotine, 2012; Giroud et al., 2015).

Проте частішають випадки, коли як основу зазначених вище рідин для паріння використовують наркотичні засоби і психотропні речовини 3 рослин роду коноплі. При цьому через екстракцію етиловим спиртом (або ізопропанолом) отримують насичений смолою екстракт канабісу, змішують його з рідиною для паріння та витримують на водяній бані для випаровування надлишку розчинника. Канабіноїди з такої рідинної суміші (як і в разі з нікотином) випаровуються вже за температури $t=140{ }^{\circ} \mathrm{C}$ (найкращі умови за $t=170{ }^{\circ} \mathrm{C}$ ), і людина споживає активні речовини через пару, максимально насичену канабіноїдами, адже вони не розбавляються побічними продуктами горіння, утворюваними під час куріння звичайним способом (Kavvalakis et al., 2015; Peace, Stone, Poklis, J., Turner, \& Poklis, A., 2016; Peace, Butler, Wolf, Poklis, J., \& Poklis, A., 2016; Poklis, Mulder, \& Peace, 2019; Stradaet li uroven TGK, 2017; Veyperam: kak sdelat zhidkost, 2017).

3-за кордону до України також потрапляють рідини для вейпорайзерів, легалізовані в деяких країнах (наприклад США) завдяки низькому вмісту (як правило до 0,3 \%) психотропної речовини тетрагідроканабінолу (далі - ТГК) та які містять значну кількість непідконтрольного сьогодні в нашій державі канабідіолу (КБД).

Судово-експертне дослідження рідин вейпорайзерів, у тому числі з'ясування кількісного вмісту їх складників (зокрема ТГК), пов'язане 3 певними обставинами, зумовленими насамперед необхідністю визначити методологічні засади пробопідготовки до проведення дослідження. Натепер окреслено лише основні підходи до екстракції канабіноїдів, використовуваних під час підготування проб для їх подальшого аналізу (Davydiuk et al., 2009). Бракує такої інформації й іншим джерелам (Aubakirov, Voronkov, Daurskih, \& Orlov, 1982; Shymanovskyi, Mashkin, Zamoshets, \& Semenova, 1997; Organizatciia Obedinennykh Natcii, 2010; Ramirez, Fanovich, \& Churio, 2019; Morski, 2020). Через недосконалість методологічного інструментарію, нерозвиненість методології, методів й інструментів пробопідготовки сумішей для паріння на основі гліцерину та пропіленгліколю з метою ї подальшого гравіметричного (визначення сухого залишку екстракту канабісу) та газохроматографічного (кількісного визначення ТГК) дослідження постає питання підбору оптимального розчинника для їх екстракції та окреслення послідовності іiі проведення. Крім того, у складі рідин можуть бути речовини, які мають близький до ТГК час утримання, а отже «виходять» із хроматографічної колон- 
ки одночасно з ним одним аналітичним сигналом («піком»), що суттєво ускладнює кількісне (а в окремих випадках і якісне) визначення ТГК методом газорідинної хроматографії з полум'яно-іонізаційним детектуванням.

Окремі аспекти зазначеної проблематики в різні часи вивчали як науковці, так і практики. Серед них В. В. Вартузов, П. П. Давидюк, О. П. Замошець, Ф. М. Кахановський, В. Т. Машкін, Р. А. Мелешко, О. О. Посільський, С. І. Стальмахович, С. О. Шимановський, які у своїх методиках запропонували схему пробопідготовки і дослідження екстрактів канабісу, отриманого за допомогою екстракції рослинними (здебільшого ненасиченими) і тваринними (насиченими) жирами, зокрема й згущеним молоком. Крістіан Жиро (Christian Giroud), Матхаус Каввалакіс (Matthaios P. Kavvalakis), Мішель Пic (Michelle R. Peace), Джастин Покліз (Justin L. Poklis) розглядали психоактивні речовини, використовувані для виготовлення наркотичних засобів на основі рідин, застосовуваних в електронних пристроях для куріння. Разом із тим сьогодні на часі поглиблене дослідження рідин, у складі яких міститься екстракт канабісу, наприклад питання пробопідготовки до дослідження з метою обгрунтованої інтерпретації отриманих результатів та формулювання однозначного висновку.

\section{Мета й завдання дослідження}

Метою статті є розроблення деяких теоретичних положень і науково-обгрунтованих практичних рекомендацій щодо дослідження рідин, застосовуваних в електронних пристроях для куріння, зокрема послідовності пробопідготовки рідин на основі гліцериново-пропіленгліколевих сумішей, використовуваних в електронних сигаретах, для подальшого їх якісного та кількісного дослідження із застосуванням методів хромато-мас-спектрометрії і газорідинної хроматографії.

Для досягнення зазначеної мети слід вирішити такі завдання:

окреслити основні проблеми дослідження гліцериново-пропіленгліколевих рідин та їх сумішей, зокрема на етапі пробопідготовки;

запропонувати і відпрацювати методологію пробопідготовки дослідження рідин на основі гліцериново-пропіленгліколевих сумішей, використовуваних в електронних сигаретах, для подальшого їх якісного та кількісного дослідження із застосуванням методів хромато-мас-спектрометрії та газорідинної хроматографії;

експериментально перевірити можливість якісного та кількісного визначення ТГК методом газорідинної хроматографії з полум'яно-іонізаційним детектуванням, визначити особливості таких досліджень; узагальнити експериментально отримані дані порівняльного дослідження екстракції ТГК із рідин для паріння трьома різними органічними розчинниками;

проаналізувати наявні тепер способи приготування наркотичних засобів, отриманих із конопель на основі рідин для вейпорайзерів, коли відсутність характерного їдкого диму дозволяє маскувати їх вживання.

\section{Виклад основного матеріалу}

На прикладі рідин для вейпорайзерів, легалізованих у деяких країнах через низький вміст психотропної речовини - ТГК, що містять при цьому значну кількість непідконтрольного сьогодні на території України КБД, відпрацьовано пробопідготовку для їх дослідження методами хромато-мас-спектрометрії та газорідинної хроматографіï за єдиного загального підходу до дослідження рідин на основі гліцериново-пропіленгліколевих сумішей незалежно від способу насичення їх екстрактом канабісу.

Дослідження рідин для вейпорайзерів проводили на об’єктах, що надійшли до ДНДЕКЦ МВС у двох картонних коробках біло-зеленого кольору з написами «Sensi Seeds ... CBD E-Liquid 10ml ...», які містили два флакони з полімерного матеріалу з такими самими написами на етикетках, закриті полімерними кришками білого кольору з прозорою і безбарвною в'язкою рідиною масою 11,011 i 10,921 г (рис. 1).

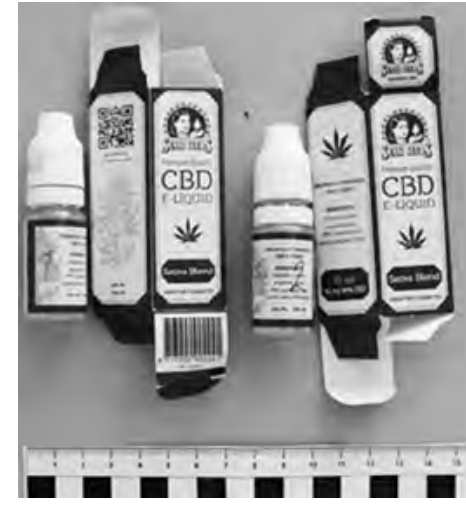

Рис. 1. Зовнішній вигляд упакування рідин для паріння, наданих на дослідження, що містилися у двох коробках

\section{Пробопідготовка}

Основні властивості рідин для паріння, зумовлені їнім хімічним складом, дають можливість визначити послідовність проведення пробопідготовки $з$ метою дослідження їх аналітичними методами, зокрема газової хроматографiï 3 полум'яно-іонізаційним детектуванням і мас-селективним детектуванням. Для експериментального підтвердження здійснено відбір двох паралельних наважок рідин масою 7,0138 і 6,9741 г, 
які розмістили у двох окремих пробірках. До кожної 3 них додали по 14 мл дистильованої води, підкисленої (United Nations Office on Drugs and Crime, 1995) хлороводневою кислотою до $\mathrm{pH} \approx 4-5$ (щоб зменшити в'язкість досліджуваної рідини та покращити екстракцію канабіноїдів у підкисленому водному розчині), і ретельно перемішали. Ці водні розчини екстрагували трьома порціями гексану об’ємом 6,5 мл кожна та однією порцією гексану об'ємом 3,2 мл (можна використовувати діетиловий ефір або інший розчинник відповідної полярності)*. Екстракти кожної паралелі об’єднали (рис. 2).

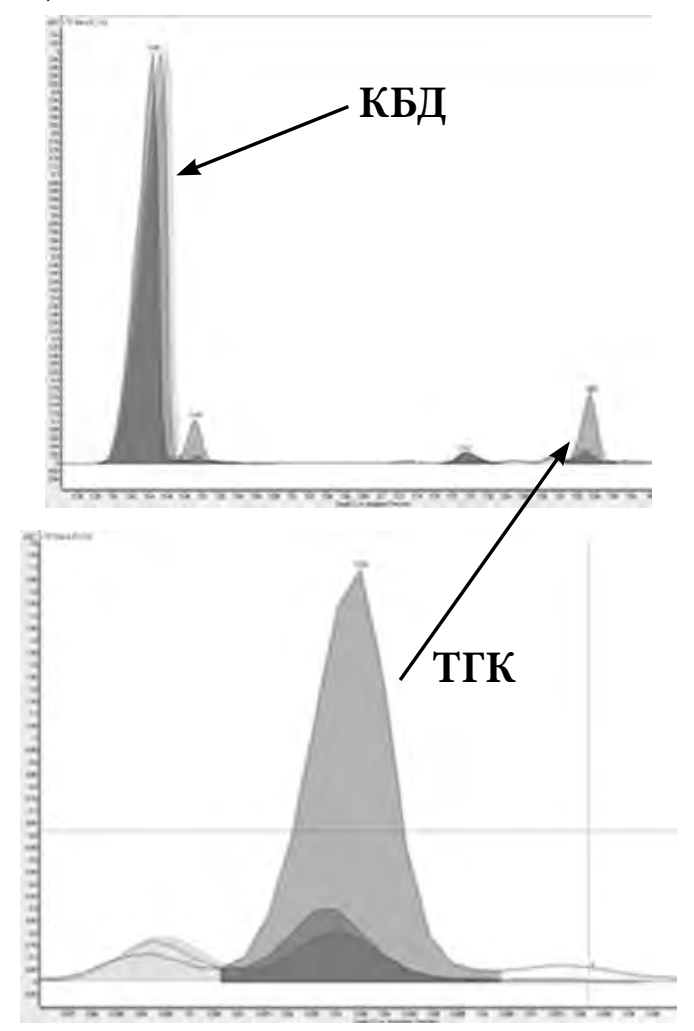

Рис. 2. Зображення порівняльного накладення хроматограм екстрактів, отриманих екстракцією однакових наважок досліджуваної рідини однією порцією (2 мл) таких розчинників: хлороформу хроматограма зеленого кольору; діетилового ефіру хроматограма фіолетового кольору; гексану хроматограма червоного кольору) * *

Отримані в такий спосіб екстракти експерт згідно з п. 8.2 Міжвідомчої методики дослідження наркотичних засобів із рослин конопель та маку снотворного (Davydiuk et al., 2009) інтерпретує як екстракт канабісу (за наявності ТГК), масу якого

${ }^{\star}$ Основний принцип підбору кількості порцій та об’єма екстрагента - досягнення якомога меншої концентрації діючої речовини (або взагалі її відсутності) в останній порції екстракційної рідини, оскільки вміст канабіноїдів (зокрема ТГК) у рідинах може бути різний.

${ }^{*}$ Кольорову гаму рисунка можна спостерігати в електронній версії наукової статті (https:/visnyk. dndekc.mvs.gov.ua/index.php/visnuk). визначають у перерахунку на суху речовину, випаровуючи розчинник.

Коли необхідно визначити кількість ТГК у цих рідинах, можна використовувати метод газорідинної хроматографії з полум'яно-іонізаційним детектуванням.

Дослідження методом газорідинної хроматографії (з метою кількісного визначення ТГК)

Отримані під час пробопідготовки сухі залишки двох паралелей розчиняли в 4,8 мл метанолу кожну, аналізували на хроматографі з полум'яно-іонізаційним детектуванням.

Умови хроматографування:

прилад - GC HP 6890 Agilent Technologies № US00039428;

капілярна колонка - НP 19091S-433 (HP-5MS), довжиною 30 м, діаметром 0,25 мм, фаза являє собою полімери на основі кремнію (полісилоксани), поліетиленгліколі і тверді адсорбенти товщиною 0,25 мкм, нанесені по всьому внутрішньому діаметру поверхні колонки; постійний потік 1,2 мл/хв, газ-носій - гелій;

інжектор - автоінжектор 7683, Split 20:1, температура випарника $t=250{ }^{\circ} \mathrm{C}$;

піч $-t_{\text {поч. }}=100^{\circ} \mathrm{C}$, утримання $2 \mathrm{xв}$, нагрівання

$15 \mathrm{C} / \mathrm{XB}, t_{\text {кінц. }}=280^{\circ} \mathrm{C}$, утримання $10 \mathrm{xB}$;

детектор - полум'яно-іонізаційний;

проба - 1,0 мкл

Ідентифікували сполуку за часом утримання (рис. 3).

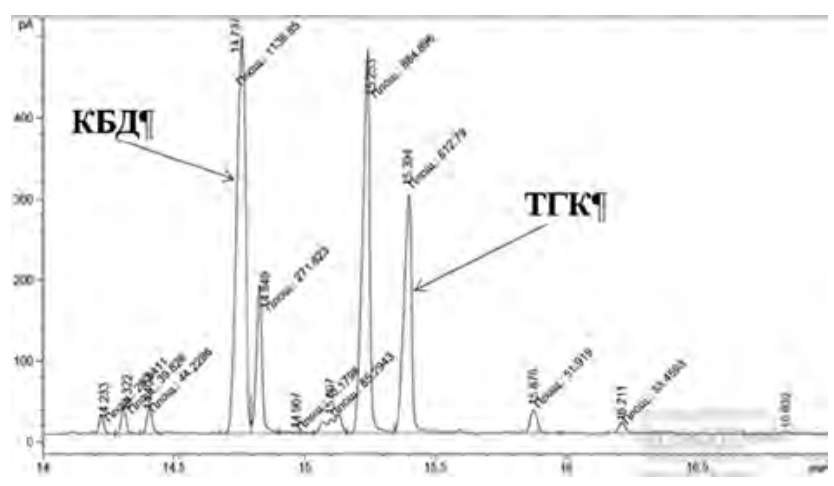

Рис. 3. Хроматограма, отримана методом хроматографії з полум'яно-іонізаційним детектуванням (час утримання КБД - 14,737 хв, ТГК - 15,394 хв)

Проте визначити кількість ТГК за допомогою методу газорідинної хроматографії з полум'яноіонізаційним детектуванням неможливо, коли у складі рідин $є$ також речовини, що мають за окреслених вище умов аналізу дуже близький до ТГК час утримання (Yamamoto, Gohda, Narimatsu, \& Yoshimura, 1988) - такою в досліджуваній рідині виявився канабієлсоїн. Накладення цих речовин можна виявити лише в разі застосування газорідинної хроматографії з мас-селективним детектуванням (рис. 4, 5 і 6). 


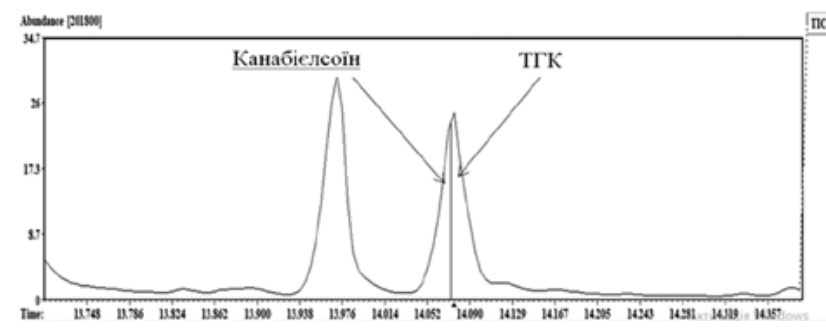

Рис. 4. Вигляд «піку» (аналітичного сигналу хроматограми), який містить дві речовини: канабієлсоїн і ТГК

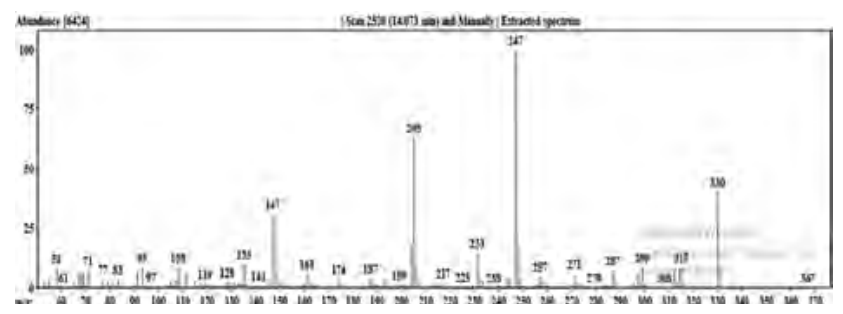

Рис. 5. Мас-спектр канабієлсоїну (RT $14.071 \mathrm{~min}$ )

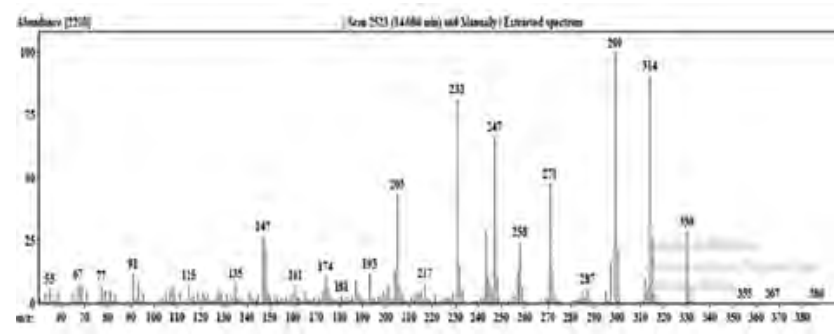

Рис. 6. Мас-спектр ТГК (RT $14.086 \mathrm{~min})$ *

Для цього дослідження отримані під час пробопідготовки розчини фільтрували та аналізували на хромато-мас-спектрометрі за таких умов:

прилад - хромато-мас-спектрометр GC/MS Agilent Technologies 6890N/5975B;

капілярна колонка - HP 19091S-433 (HP-5MS), довжиною 30 м, діаметром 0,25 мм, фаза являє собою полімери на основі кремнію (полісилоксани), поліетиленгліколі і тверді адсорбенти товщиною 0,25 мкм, нанесені по всьому внутрішньому діаметру поверхні колонки; постійний потік 1,5 мл/хв, газ-носій - гелій;

інжектор - автоінжектор 7683, Split 20:1, температура випарника $t=280^{\circ} \mathrm{C}$;

піч $-t_{\text {поч. }}=100^{\circ} \mathrm{C}$, утримання 4 хв, нагрівання $16^{\circ} \mathrm{C} / \mathrm{xB}, t_{\text {кінц. }}=280^{\circ} \mathrm{C}$, утримання $10 \mathrm{xB}$;

детектор - мас-селективний, температура інтерфейсу $t=280{ }^{\circ} \mathrm{C}$, іонізація електронним ударом, енергія іонізації $70 \mathrm{eB}$, температура іонного джерела $t=230{ }^{\circ} \mathrm{C}$; температура квадруполю $t=150^{\circ} \mathrm{C}$; режим отримання мас-спектра scan (те саме що й Total Ion Current) у діапазоні реєстрації мас $40-450 \mathrm{~m} / \mathrm{z}$;

проба - 1 мкл.

Отже, час утримання (виходу) канабієлсоїну

*Канабієлсоїн (CAS\#52025-76-0) ідентифікований як метаболіт КБД (Yamamoto, Gohda, Narimatsu, \& Yoshimura, 1988).
(RT $14.071 \mathrm{~min})$ і ТГК (RT $14.086 \mathrm{~min}$ ) збігається, розрізнити їх можна лише за мас-спектрами.

Подальше дослідження проводили із застосуванням методу SIM хромато-мас-спектрометра 3 детектуванням характерних для ТГК маси $314 \mathrm{~m} / \mathrm{z}$ та часу утримання (виходу) RT $14.071 \mathrm{~min}$ (рис. 7).

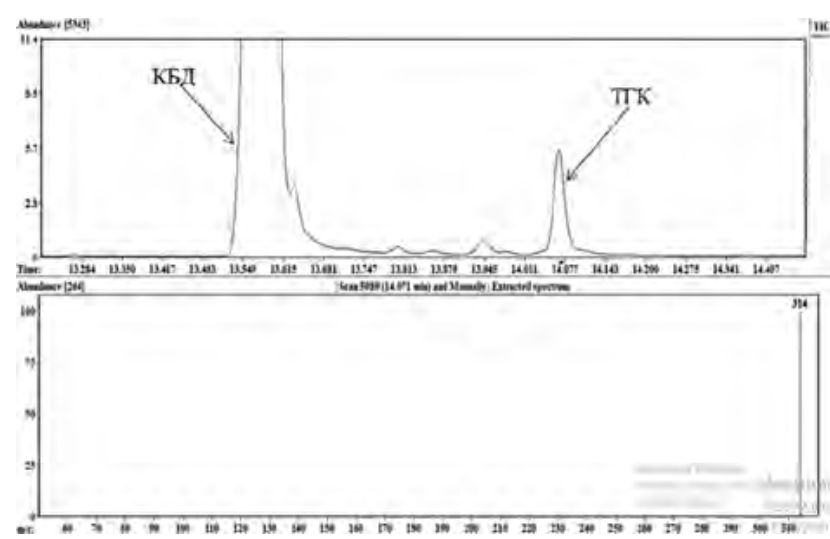

Рис. 7. Загальний вигляд хроматограми 3 мас-спектром (сканування $314 \mathrm{~m} / \mathrm{z}$ методом SIM) КБД (RT $13.603 \mathrm{~min})$ i ТГК (RT $14.071 \mathrm{~min})$

Умови аналізу:

прилад - хромато-мас-спектрометр GC/MS Agilent Technologies 6890N/5975B;

капілярна колонка - HP 19091S-433 (HP-5MS), довжиною 30 м, діаметром 0,25 мм, фаза являє собою полімери на основі кремнію (полісилоксани), поліетиленгліколі і тверді адсорбенти товщиною 0,25 мкм, нанесені по всьому внутрішньому діаметру поверхні колонки; постійний потік 1,5 мл/хв, газ-носій - гелій;

інжектор - автоінжектор 7683, Split 20:1, температура випарника $t=280^{\circ} \mathrm{C}$;

піч $-t_{\text {поч. }}=100^{\circ} \mathrm{C}$, утримання $4 \mathrm{xB}$, нагрівання $16^{\circ} \mathrm{C} / \mathrm{xB}, t_{\text {кінц. }}=280^{\circ} \mathrm{C}$, утримання $10 \mathrm{xB}$;

детектор - мас-селективний, температура інтерфейсу $t=280{ }^{\circ} \mathrm{C}$, іонізація електронним ударом, енергія іонізації $70 \mathrm{eB}$, температура іонного джерела $t=230{ }^{\circ} \mathrm{C}$; температура квадруполю $t=150{ }^{\circ} \mathrm{C}$; режим отримання мас-спектра SIM, маса, яка реєструвалася, $314 \mathrm{~m} / \mathrm{z}$;

проба - 1 мкл.

Концентрацію ТГК визначали методом зовнішнього стандарту через абсолютне калібрування.

За допомогою програми оброблення даних Chemstation встановлено:

наявність у досліджуваних рідинах КБД, психоактивної речовини ТГК, канабінолу;

середній відсотковий та кількісний вміст ТГК - 0,07 \% і 0,006 г відповідно.

\section{Наукова новизна}

Розроблено і відпрацьовано методологію пробопідготовки дослідження рідин на основі гліце- 
риново-пропіленгліколевих сумішей, використовуваних в електронних сигаретах, для подальшого ix якісного та кількісного дослідження із застосуванням методів хромато-мас-спектрометрії та газорідинної хроматографії.

\section{Висновки}

1. Окреслено основні проблеми дослідження гліцериново-пропіленгліколевих рідин та їх сумішей, зокрема на етапі пробопідготовки, коли за браком чіткої методичної регламентації цього процесу експерти мусять вдаватися до експериментального підбору оптимального розчинника для екстракції та самостійно встановлювати порядок іï проведення з метою їх подальшого гравіметричного (визначення сухого залишку екстракту канабісу) та газохроматографічного (кількісного визначення ТГК) дослідження.

2. Запропоновано методологію пробопідготовки дослідження рідин на основі гліцериново-пропіленгліколевих сумішей, використовуваних в електронних сигаретах, для подальшого їх якісного та кількісного дослідження із застосуванням методів хромато-мас-спектрометрії та газорідинної хроматографії.

3. Експериментально доведено неможливість кількісного (а в окремих випадках і якісного) визначення ТГК методом газорідинної хроматографії з полум'яно-іонізаційним детектуванням через наявність у складі гліцериново-пропіленгліколевих рідин речовин, які мають близький до ТГК час утримання та «виходять» із хроматографічної колонки разом із ним одним аналітичним сигналом («піком»). Підтверджено можливість вирішення цього завдання за допомогою хромато-мас-спектрометричного комплексу із застосуванням методу вибіркового сканування іонів (SIM) у разі, коли неможливо підібрати умови для хроматографічного розділення ТГК у суміші з іншими супутніми компонентами.

4. Узагальнено експериментально отримані дані порівняльного дослідження екстракції ТГК із водних розчинів рідин для паріння трьома різними органічними розчинниками, які доводять, що у нашому випадку діетиловий ефір проявляє дещо кращі екстракційні властивості щодо канабіноїдів, але залежно від супутніх компонентів матриці схожих досліджуваних об'єктів цілком допустимо застосування інших органічних розчинників (хлороформу, гексану тощо) з додатковими кількостями порцій екстрагенту для досягнення більшої повноти вилучення екстрагованого аналіту.

5. Проаналізовано способи приготування наркотичних засобів і психотропних речовин, отриманих із рослин конопель, на основі рідин для вейпорайзерів. Наголошено на тому, що вони відносно нескладні, а відсутність характерного їдкого диму дозволяє маскувати їх вживання. Тому убачається на часі, оскільки формування демократичного суспільства і розбудова інституцій правової держави потребують унормування усіх сфер життєдіяльності суспільства, на законодавчому рівні розтлумачити і чітко дефініювати поняття «електронні сигарети», врегулювати ї обіг, зважаючи на ті ризики, що сьогодні постають перед державою.

\section{References}

Aubakirov, A. F., Voronkov, Yu. M., Daurskih, V. K., \& Orlov, Yu. K. (1982). Kriminalisticheskoe issledovanie narkoticheskih veschestv kustarnogo izgotovleniya. M.: Ministerstvo yustitsii SSSR. 121 s. [in Russian].

Davydiuk, P. P., Vartuzov, V. V., Posilskyi, O. O., Zamoshets, O. P., Kakhanovskyi, F. M., Stalmakhovych, S. I., \& Meleshko, R. A. (2009). Mizhvidomcha metodyka doslidzhennia narkotychnykh zasobiv z roslyn konopel ta maku snotvornoho / za red. P. P. Davydiuka. Kyiv: DNDEKTs MVS Ukrainy. 80 s. [in Ukrainian].

Giroud, C., de Cesare, M., Berthet, A., Varlet, V., Concha-Lozano, N., \& Favrat, B. (2015, Aug., 21). E-Cigarettes: A Review of New Trends in Cannabis Use. International Journal of Environmental Research and Public Health, 12 (8), $9988-$ 10008. Retrieved from https://europepmc.org/article/MED/26308021.

DOI: 10.3390/ijerph120809988.

Kavvalakis, M. P., Stivaktakis, P. D., Tzatzarakis, M. N., Kouretas, D., Liesivuori, J., Alegakis, A. K., Vynias, D., \& Tsatsakis, A. M. (2015, May). Multicomponent Analysis of Replacement Liquids of Electronic Cigarettes Using Chromatographic Techniques. Journal of Analytical Toxicology (Vol. 39 (4), p. 262-269). Retrieved from https://academic. oup.com/jat/article/39/4/262/749914.

DOI: $10.1093 /$ jat/bkv002.

Morski, L. M. (2020). The Complete Guide to CBD Extractions (CO2, Olive Oil, Solvents). Retrieved from https://wayofleaf. $\mathrm{com} /$ cannabis/101/cbd-cannabis-extraction.

Nicotine. (2012). National Library of Medicine. National Center for Biotechnology Information. Retrieved from https:// pubchem.ncbi.nlm.nih.gov/compound/Nicotine\#section=Odor.

Obzor komponentov dlya izgotovleniya zhidkosti. (2015). Vzyato iz https://xn--80aaxitdbjk.xn--plai/reviews/obzor-komponentov-dlja-izgotovlenija-zhidkosti/ [in Russian].

Organizatciia Obedinennykh Natcii. (2010). Rekomenduemye metody identifikatcii I analiza kannabisa $i$ produktov kannabisa: rukovodstvo dlia natcionalnykh laboratorii ekspertizy narkotikov (peresmotrennoe i dopolnennoe izdanie). Niu-Iork. 52 s. [in Russian]. 
Peace, M. R., Butler, K. E., Wolf, C. E., Poklis, J. L., \& Poklis, A. (2016, Aug., 29). Evaluation of Two Commercially Available Cannabidiol Formulations for Use in Electronic Cigarettes. Frontiers Pharmacology, 7 (279). Retrieved from https:// www.ncbi.nlm.nih.gov/pmc/articles/PMC5002419/.

DOI: $10.3389 /$ fphar.2016.00279.

Peace, M. R., Stone, J. W., Poklis, J. L., Turner, J. B. M., \& Poklis, A. (2016, Jun.). Analysis of a Commercial Marijuana e-Cigarette Formulation. Journal of Analytical Toxicology, 40 (5), 374-378. Retrieved from https://www.ncbi.nlm.nih.gov/ pmc/articles/PMC4867395/.

DOI: $10.1093 /$ jat/bkw021.

Poklis, J. L., Mulder, H. A., \& Peace, M. R. (2019, Jan.). The Unexpected Identification of the Cannabimimetic, 5F-ADB, and Dextromethorphan in Commercially Available Cannabidiol e-liquids. Forensic Science International (Vol. 294, p. 25-27). Retrieved from https://pubmed.ncbi.nlm.nih.gov/30442388/.

DOI: $10.1016 /$ j.forsciint.2018.10.019.

Pro vprovadzhennia metodychnykh rekomendatsii shchodo klasyfikatsii okremykh tovariv zghidno z vymohamy UKTZED: lyst Ministerstva dokhodiv i zboriv Ukrainy № 6983/7/99-99-24-02-03-17. (2014) [in Ukrainian].

Ramirez, C. L., Fanovich, M. A., \& Churio, M. S. (2019). Chapter 4. Cannabinoids: Extraction Methods, Analysis, and Physicochemical Characterization, Studies in Natural Products Chemistry (Vol. 61, p. 143-173).

DOI: https://doi.org/10.1016/B978-0-444-64183-0.00004-X.

Shymanovskyi, S. O., Mashkin, V. T., Zamoshets, O. P., \& Semenova, I. V. (1997). Doslidzhennia narkotykiv, poshyrenykh na terytorii Ukrainy. Kyiv: RVV MVS Ukrainy. 92 s. [in Ukrainian].

Stradaet li uroven TGK cherez vaporaizer dlia kureniia. (2017). Ganjalive. Vzyato iz http://ganjalive.pro/topic/19806-stradaet-li-uroven-tgk-cherez-vaporajzer-dlia-kureniia/ [in Russian].

United Nations Office on Drugs and Crime. (1995). Recommended Methods for the Detection and Assay of Heroin, Cannabinoids, Cocaine, Amphetamine, Methamphetamine and Ring-Substituted Amphetamine Derivatives in Biological Specimens. 88 p. Retrieved from https://www.unodc.org/unodc/en/scientists/recommended-methods-for-the-detection-and-assay-of-heroin--cannabinoids--cocaine--amphetamine--methamphetamine.html.

Veyperam: kak sdelat zhidkost na marihuane? (2017). Kanna.biz. Vzyato iz http://d.kannabiz.name/mir-o-marikhuane/ vejperam-kak-sdelat-zhizhku-na-marihuane [in Russian].

Yamamoto, I., Gohda, H., Narimatsu, S., \& Yoshimura, H. (1988, Dec.). Identification of Cannabielsoin, a New Metabolite of Cannabidiol Formed by Guinea-Pig Hepatic Microsomal Enzymes, and Its Pharmacological Activity in Mice. Journal of Pharmacobio-dynamics (Vol. 11 (12), p. 833-838). Retrieved from https://pubmed.ncbi.nlm.nih.gov/3254981/. DOI: $10.1248 / \mathrm{bpb} 1978.11 .833$.

\section{Список використаних джерел}

Аубакиров, А. Ф., Воронков, Ю. М., Даурских, В. К., \& Орлов, Ю. К. (1982). Криминалистическое исследование наркотических веществ кустарного изготовления. М.: Министерство юстиции СССР. $121 \mathrm{c.}$

Давидюк, П. П., Вартузов, В. В., Посільський, О. О., Замошець, О. П., Кахановський, Ф. М., Стальмахович, С. І., \& Мелешко, Р. А. (2009). Міжвідомча методика дослідження наркотичних засобів з рослин конопель та маку снотворного / за ред. П. П. Давидюка. Київ: ДНДЕКЦ МВС України. 80 с.

Giroud, C., de Cesare, M., Berthet, A., Varlet, V., Concha-Lozano, N., \& Favrat, B. (2015, Aug., 21). E-Cigarettes: A Review of New Trends in Cannabis Use. International Journal of Environmental Research and Public Health, 12 (8), 998810008. Retrieved from https://europepmc.org/article/MED/26308021. DOI: $10.3390 /$ ijerph120809988.

Kavvalakis, M. P., Stivaktakis, P. D., Tzatzarakis, M. N., Kouretas, D., Liesivuori, J., Alegakis, A. K., Vynias, D., \& Tsatsakis, A. M. (2015, May). Multicomponent Analysis of Replacement Liquids of Electronic Cigarettes Using Chromatographic Techniques. Journal of Analytical Toxicology (Vol. 39 (4), p. 262-269). Retrieved from https://academic.oup.com/jat/article/39/4/262/749914. DOI: $10.1093 /$ jat/bkv002.

Morski, L. M. (2020). The Complete Guide to CBD Extractions (CO2, Olive Oil, Solvents). Retrieved from https://wayofleaf. com/cannabis/101/cbd-cannabis-extraction.

Nicotine. (2012). National Library of Medicine. National Center for Biotechnology Information. Retrieved from https:// pubchem.ncbi.nlm.nih.gov/compound/Nicotine\#section=Odor.

Обзор компонентов для изготовления жидкости. (2015). Взято из https://xn--80aaxitdbjk.xn--plai/reviews/obzor-komponentov-dlja-izgotovlenija-zhidkosti/.

Организация Объединенных Наций.(2010). Рекомендуемые методы идентификации и анализа каннабиса и продуктов каннабиса: руководство для национальных лабораторий экспертизы наркотиков (пересмотренное и дополненное издание). Нью-Йорк. 52 с.

Peace, M. R., Butler, K. E., Wolf, C. E., Poklis, J. L., \& Poklis, A. (2016, Aug., 29). Evaluation of Two Commercially Available Cannabidiol Formulations for Use in Electronic Cigarettes. Frontiers Pharmacology, 7 (279). Retrieved from https:// www.ncbi.nlm.nih.gov/pmc/articles/PMC5002419/.

DOI: $10.3389 /$ fphar.2016.00279.

Peace, M. R., Stone, J. W., Poklis, J. L., Turner, J. B. M., \& Poklis, A. (2016, Jun.). Analysis of a Commercial Marijuana e-Cig- 
arette Formulation. Journal of Analytical Toxicology, 40 (5), 374-378. Retrieved from https://www.ncbi.nlm.nih.gov/ pmc/articles/PMC4867395/.

DOI: $10.1093 /$ jat/bkw021.

Poklis, J. L., Mulder, H. A., \& Peace, M. R. (2019, Nov.). The Unexpected Identification of the Cannabimimetic, 5F-ADB, and Dextromethorphan in Commercially Available Cannabidiol E-liquids. Forensic Science International (Vol. 294, p. 25-27). Retrieved from https://pubmed.ncbi.nlm.nih.gov/30442388/.

DOI: 10.1016/j.forsciint.2018.10.019.

Про впровадження методичних рекомендацій щодо класифікації окремих товарів згідно з вимогами УКТЗЕД: лист Міністерства доходів і зборів України № 6983/7/99-99-24-02-03-17. (2014).

Ramirez, C. L., Fanovich, M. A., \& Churio, M. S. (2019). Chapter 4. Cannabinoids: Extraction Methods, Analysis, and Physicochemical Characterization, Studies in Natural Products Chemistry (Vol. 61, p. 143-173).

DOI: https://doi.org/10.1016/B978-0-444-64183-0.00004-X.

Шимановський, С. О., Машкін, В. Т., Замошець, О. П., \& Семенова, І. В. (1997). Дослідження наркотиків, поширених на території України. Київ: РВВ МВС України. 92 с.

Страдает ли уровень ТГК через вапорайзер для курения. (2017). Ganjalive. Взято из http://ganjalive.pro/topic/19806stradaet-li-uroven-tgk-cherez-vaporajzer-dlia-kureniia/.

United Nations Office on Drugs and Crime. (1995). Recommended Methods for the Detection and Assay of Heroin, Cannabinoids, Cocaine, Amphetamine, Methamphetamine and Ring-Substituted Amphetamine Derivatives in Biological Specimens. 88 p. Retrieved from https://www.unodc.org/unodc/en/scientists/recommended-methods-for-the-detection-and-assay-of-heroin--cannabinoids--cocaine--amphetamine--methamphetamine.html.

Вейперам: как сделать жидкость на марихуане? (2017). Kanna.biz. Взято из http://d.kannabiz.name/mir-omarikhuane/vejperam-kak-sdelat-zhizhku-na-marihuane.

Yamamoto, I., Gohda, H., Narimatsu, S., \& Yoshimura, H. (1988, Dec.). Identification of Cannabielsoin, a New Metabolite of Cannabidiol Formed by Guinea-Pig Hepatic Microsomal Enzymes, and Its Pharmacological Activity in Mice. Journal of Pharmacobio-dynamics (Vol. 11 (12), p. 833-838). Retrieved from https://pubmed.ncbi.nlm.nih.gov/3254981/. DOI: $10.1248 / \mathrm{bpb} 1978.11 .833$.

Стаття надійшла до редакиї 23.12.2019

O. Zavialov, Head of the Sector

for Certification of Standard Samples

of Narcotic Drugs, Psychotropic Substances,

their Analogues and Precursors,

Research of Narcotic Drugs, Psychotropic Substances,

their Analogues and Precursors Department,

Research Materials, Substances and Products Laboratory,

State Scientific Research Forensic Center, MIA of Ukraine,

Kyiv, Ukraine

ORCID: https://orcid.org/0000-0002-4697-0841

N. Zavialova, Chief Forensic Expert

of Physicochemical Researches Department,

Materials, Substances and Products Research Laboratory,

State Scientific Research Forensic Center, MIA of Ukraine,

Kyiv, Ukraine

ORCID: https://orcid.org/0000-0002-6483-8190

\title{
INVESTIGATION OF LIQUIDS USED IN VAPING DEVICES
}

\begin{abstract}
The purpose of the article is to develop some theoretical provisions and scientifically-based practical recommendations concerning investigation of e-liquids used in vaping devices, in particular, the sequence of sample preparation of liquids. e-Liquids, presented in the mixture as a ratio of glycerol and propylene glycol, were further qualitatively and quantitatively analyzed by chromate-mass spectrometry and gas-liquid chromatography. Methodology. The methodological basis of the study are general scientific and partial methods of scientific knowledge. Their comprehensive application allowed to clearly define the purpose and tasks of the study in the context of the combination of scientific achievements and the requirements of forensic practice. e-Liquids, containing drugs and psychotropic substances derived from plants hemp, were analyzed for vaping devices with the help of empirical methods (in view of the logic of the cognitive process it is a component of general scientific methods and of general logic), such as description, analysis, measurement, comparison, observation, experiment. Whereas the absence of characteristic pungent smoke allow
\end{abstract}


masking their use in such way. The possibility of qualitative and quantitative determination of tetrahydrocannabinol by gas-liquid chromatography with mass-selective and flame-ionization detection was analyzed and experimentally tested, the features of such studies were outlined. Partial methods were used to study specific phenomena of chemical and biological nature. Intermediate and final calculations of the experiment were performed by mathematical methods. Scientific novelty. The methodology of sample preparation of e-liquids based on glycerin-propylene glycol mixtures used in e-cigarettes has been developed for their further qualitative and quantitative determination by chromate-mass spectrometry and gas-liquid chromatography. Conclusions. The main problems of investigation of e-liquids based on glycerol-propylene glycol mixtures are outlined, in particular, at the step of sample preparation process. In the absence of clear methodological regulation of the process, experts must resort to experimental selection of the optimal solvent for extraction and they must establish the sequence for their further gravimetric analysis (determination of dry residue of cannabis extract) and gas chromatography determination (analytical quantification of tetrahydrocannabinol). Methodology for sample preparation of e-liquids based on glycerol-propylene glycol mixtures used in e-cigarettes was proposed. It could be useful for their further qualitative and quantitative analysis by chromate-mass spectrometry and gas-liquid chromatography. The impossibility of quantitative (and in some cases qualitative) determination of tetrahydrocannabinol by gas-liquid chromatography with flame ionization detection experimentally proved due to the presence in the composition of glycerol-propylene glycol liquids that have close retention time to the that one for tetrahydrocannabinol and «come out» of the column as one analytical signal («peak»). The possibility of solving this problem was proved by chromate-mass spectrometry using selective ion scanning mode (Selective Ion Monitoring) in the case when it is impossible to select conditions for chromatographic separation of tetrahydrocannabinol in a mixture with other related components. Experimental data for a comparative study of the extraction of tetrahydrocannabinol from aqueous solutions were analyzed for steaming with three different organic solvents. As a result, it was found that diethyl ether exhibits slightly better extraction properties for the investigated object; methods for drug preparation from hemp were analyzed on the basis of e-liquids for vaping devices. It is emphasized that these methods of preparation are relatively simple, and the lack of characteristic pungent smoke allows masking their use. Therefore, under this consideration, it is necessary to form a democratic society and developing of institutions and a state governed by the rule of law. They require normalization of all spheres of society. In the view of the risks facing today, it would be good to interpret and clearly define the concept of «e-cigarettes», to regulate their circulation at the legislative level.

Keywords: cannabis extract; tetrahydrocannabinol; cannabidiol; chromate-mass spectrometry; gas-liquid chromatography; electronic cigarette (vaping devices).

\author{
А. С. Завьялов, заведующий сектором сертибикации \\ стандартных образиов наркотических средств, \\ психотропных веществ, их аналогов и прекурсоров \\ отдела исследований наркотических средств, \\ психотропных веществ, их аналогов и прекурсоров \\ лаборатории исследования материалов, вещзеств и изделий, \\ Государственный научно-исследовательский экспертно- \\ криминалистический иентр МВД Украины, г. Киев \\ ORCID: https://orcid.org/0000-0002-4697-0841 \\ Н. Е. Завьялова, главныцй судебный эксперт \\ отдела физико-химических исследований \\ лаборатории исследования материалов, веществ и изделий, \\ Государственный научно-исследовательский экспертно- \\ криминалистический иентр МВД Украинь, г. Киев \\ ORCID: https://orcid.org/0000-0002-6483-8190
}

\title{
ИССЛЕДОВАНИЕ ЖИДКОСТЕЙ, ПРИМЕНЯЕМЫХ В ЭЛЕКТРОННЫХ УСТРОЙСТВАХ ДЛЯ КУРЕНИЯ
}

\footnotetext{
Цель статьи заключается в разработке некоторых теоретических положений и научно обоснованных практических рекомендаций по исследованию жидкостей, применяемых в электронных устройствах для курения, в частности порядка пробоподготовки жидкостей на основе глицериново-пропиленгликолевых смесей, используемых в электронных сигаретах, для дальнейшего их качественного и количественного исследования с применением методов хромато-масс-спектрометрии и газожидкостной хроматографии. Методология. Методологическую основу исследования составляют общенаучные и частные методы научного познания, комплексное применение которых позволило четко сформулировать цель и задачи исследования в контексте взаимодействия научных достижений и потребностей судебно-экспертной практики. При этом с помощью эмпирических методов (составляющей общенаучных или общелогических методов с точки зрения логики познавательного процесса), таких как описание, анализ, измерение, сравнение, наблюдение, экспе-
} 
римент проанализированы жидкости для вейпорайзеров, изготовленные с использованием наркотических средств и психотропных веществ, полученных из растений конопли, когда отсутствие характерного едкого дыма позволяет маскировать их употребление таким способом; проанализирована и экспериментально проверена возможность качественного и количественного определения тетрагидроканнабинола методом газожидкостной хроматографии с масс-селективным и пламенно-ионизационным детектированием, определены особенности таких исследований. Частичные методы применены для исследования конкретных явлений химической и биологической природы. Математическими методами произведены промежуточные и окончательные расчеты эксперимента. Научная новизна. Разработана и отработана методология пробоподготовки исследования жидкостей на основе глицериново-пропиленгликолевых смесей, используемых в электронных сигаретах, для дальнейшего их качественного и количественного исследования с применением методов хромато-масс-спектрометрии и газожидкостной хроматографии. Выводы. Очерчены основные проблемы исследования глицерино-пропиленгликолевых жидкостей и их смесей, в частности на этапе пробоподготовки, когда при отсутствии четкой методической регламентации этого процесса эксперты вынуждены прибегать к экспериментальному подбору оптимального растворителя для экстракции и самостоятельно устанавливать порядок ее проведения с целью их дальнейшего гравиметрического (определения сухого остатка экстракта каннабиса) и газохроматографического (количественного определения тетрагидроканнабинола) исследования; предложена методология пробоподготовки исследования жидкостей на основе глицерино-пропиленгликолевых смесей, используемых в электронных сигаретах, для дальнейшего их качественного и количественного исследования с применением методов хромато-масс-спектрометрии и газожидкостной хроматографии; экспериментально доказана невозможность количественного (а в отдельных случаях и качественного) определения тетрагидроканнабинола методом газожидкостной хроматографии с пламенно-ионизационным детектированием из-за наличия в составе глицерино-пропиленгликолевых жидкостей веществ, которые имеют близкое к тетрагидроканнабинолу время удерживания и «выходят» из хроматографической колонки вместе с ним одним аналитическим сигналом («пиком»). Подтверждена возможность решения этой задачи при помощи хромато-масс-спектрометрического комплекса с применением метода выборочного сканирования ионов (Selective Ion Monitoring) в случае, когда невозможно подобрать условия для хроматографического разделения тетрагидроканнабинола в смеси с другими сопутствующими компонентами; проанализированы полученные экспериментальным путем данные сравнительного исследования экстракции тетрагидроканнабинола из водных растворов жидкостей для парения тремя различными органическими растворителями, в результате установлено, что диэтиловый эфир проявляет несколько лучшие экстракционные свойства по отношению к исследуемому объекту, рассмотрены способы приготовления наркотических средств и психотропных веществ, полученных из растений конопли, на основе жидкостей для вейпорайзеров. Отмечено, что эти способы приготовления относительно несложны, а отсутствие характерного едкого дыма позволяет маскировать их применение. Поэтому представляется актуальным, поскольку формирование демократического общества и развитие институтов правового государства требуют нормирования всех сфер жизнедеятельности общества, на законодательном уровне разъяснить и четко дефинировать понятие «электронные сигареты», урегулировать их оборот, учитывая те риски, которые сегодня стоят перед государством.

Ключевые слова: экстракт каннабиса; тетрагидроканнабинол; каннабидиол; хромато-масс-спектрометрия; газожидкостная хроматография; электронная сигарета (вейпорайзер). 